\title{
Characterization of dual specificity protein kinase from maize seedlings
}

\author{
Joanna B. Trojanek, Maria M. Klimecka, Anna Fraser, Grażyna Dobrowolska \\ and Grażyna Muszyńska ${ }^{凶}$
}

\section{Institute of Biochemistry and Biophysics, Polish Academy of Sciences, Warszawa, Poland}

Received: 24 January, 2004; revised: 26 April, 2004; accepted: 17 May, 2004

Key words: maize, tyrosine phosphorylation, dual specificity kinase

\begin{abstract}
A protein kinase of $57 \mathrm{kDa}$, able to phosphorylate tyrosine in synthetic substrates $\operatorname{pol}\left(\mathrm{Glu}_{4}, \mathrm{Tyr}_{1}\right)$ and a fragment of Src tyrosine kinase, was isolated and partly purified from maize seedlings (Zea mays). The protein kinase was able to phosphorylate exogenous proteins: enolase, caseins, histones and myelin basic protein. Amino acid analysis of phosphorylated casein and enolase, as well as of phosphorylated endogenous proteins, showed that both Tyr and Ser residues were phosphorylated. Phosphotyrosine was also immunodetected in the $57 \mathrm{kDa}$ protein fraction. In the protein fraction there are present $57 \mathrm{kDa}$ protein kinase and enolase. This co-purification suggests that enolase can be an endogenous substrate of the kinase. The two proteins could be resolved by two-dimensional electrophoresis. Specific inhibitors of typical protein-tyrosine kinases had essentially no effect on the activity of the maize enzyme. Staurosporine, a nonspecific inhibitor of protein kinases, effectively inhibited the $57 \mathrm{kDa}$ protein kinase. Also, poly L-lysine and heparin inhibited tyrosine phosphorylation by $57 \mathrm{kDa}$ maize protein kinase. The substrate and inhibitor specificities of the $57 \mathrm{kDa}$ maize protein kinase phosphorylating tyrosine indicate that it is a novel plant dual-specificity protein kinase.
\end{abstract}

Although protein Tyr phosphorylation is a rare post-translational event (Cooper et al., 1983), its importance in controlling fundamental cellular processes such as growth, pro- liferation, and differentiation has been well established (Uchida et al., 1994). In mammals, tyrosine phosphorylation is catalysed by both specific (receptor and cytoplasmic)

\footnotetext{
${ }^{凶}$ Corresponding author: Grażyna Muszyńska, Institute of Biochemistry and Biophysics, Polish Academy of Sciences, A. Pawińskiego 5a, 02-106 Warszawa, Poland; e-mail: muszynsk@ibb.waw.pl

Abbreviations: 2DE, two-dimensional electrophoresis; DSK, dual-specificity kinase; MAPK, mitogen activated protein kinase; MAPKK, MAPK kinase; MBP, myelin basic protein; PK, protein kinase; PTK, protein-tyrosine kinase; RR-Src, fragment of Src tyrosine kinase.
} 
protein tyrosine kinases (PTKs, reviewed in Hunter, 1998) and DSKs (Dual Specificity Protein Kinases) which, in addition to Tyr, also phosphorylate Ser and/or Thr residues (reviewed in Lindberg et al., 1992; Dhanasekaran \& Reddy, 1998).

To date, Tyr phosphorylation of plant proteins has not been sufficiently elucidated. Although this modification has been observed in many plant species (Elliot \& Geytenbeek, 1985; Torruella et al., 1986; Trojanek et al., 1996), its function remains unknown. There are only few reports on this matter. It was determined that profilin (from Phaseolus vulgaris), a component of the actin cytoskeleton, contained phosphotyrosine (Guillén et al., 1999). Recently, reversible tyrosine phosphorylation has been suggested to play an important role in the regulation of stomatal function in Arabidopsis (Luan, 2002). Also, Tyr phosphorylation of low molecular mass proteins of pea mitochondria seems to be involved in respiratory redox signalling (Håkansson \& Allen, 1995). In pea mitochondria, coconut embryos, and transformed roots of Catharanthus roseus, tyrosine phosphorylation is inhibited by genistein (Håkansson \& Allen, 1995; Islas-Flores et al., 1998; Rodriguez-Zapata \& HernándezSotomayor, 1998), a specific inhibitor of animal PTKs. The presence in plants of an activity of phosphorylating RR-Src (a synthetic peptide derived from Src tyrosine kinase), which can be inhibited by genistein indicates PTK activity (Islas-Flores et al., 1998; Rodriguez-Zapata \& Hernández-Sotomayor, 1998).

Isolated from Arabidopsis thaliana cDNA encoding protein kinase (APK1) comprises mosaic of sequence characteristic for Ser/Thr as well as Tyr kinases. Recombinant APK1 was able to phosphorylate several exogenous proteins on Tyr (Hirayama \& Oka, 1992). Screening of an $A$. thaliana expression library with an anti-phosphotyrosine antibody allowed cloning of another protein kinase (ADK1). Recombinant ADK1 was autophosphorylated on Ser, Thr, and Tyr residues and was able to phosphorylate Tyr in the synthetic peptide poly $\left(\mathrm{Glu}_{4}, \mathrm{Tyr}_{1}\right)$ (Ali et al., 1994).

A cDNA encoding a protein with characteristic of a receptor-like kinase (PRK1) was isolated from a Petunia inflata library (Mu et al., 1994). Recombinant cytoplasmic domain of PRK1 autophosphorylated on Ser and Tyr, suggesting that it is a DSK. The receptor-like structure of this kinase, its localization and interaction with calcium binding protein (KIP1) suggest that it modulates microtubule dynamics during pollen development (Skirpan et al., 2001).

The occurrence in plants of DSKs with essential roles in signal transduction has been well documented. Mitogen Activated Protein Kinase Kinases (MAPKKs/MEKs), the main components of MAPK cascades, phosphorylate MAPKs on both Thr and Tyr residues of the conserved activation motif (Thr-Glu-Tyr, Thr-Pro-Tyr or Thr-Gly-Tyr). In plants, as in yeast and mammals, specific MAP kinase pathways participate in transduction of a variety of stimuli, among them well recognized are ethylene signaling pathway and innate immunity cascade induced by flagellin (Morris et al., 1997; Asai, 2002; Chang, 2003; Ouaked et al. 2003; Guo \& Ecker, 2004). The best characterized is SIMPKK (ㅁalt Stress Induced MAPK Kinase). There is evidence directly demonstrating that the salt-induced activation of SIMK is mediated by the dual-specificity SIMKK (Kiegeri et al., 2000). Another plant PK phosphorylating Tyr with a defined function is the dual specificity kinase, named PK12. This is a member of the LAMMER family of PKs, related to cyclin-dependent kinases and MAPKs. Recombinant PK12 undergoes autophosphorylation in vitro on Ser, Thr, and Tyr residues. The postulated functions of tobacco PK12 are transduction of ethylene signal(s) (Sessa et al., 1996) and alternative splicing modulation (Savaldi-Goldstein et al., 2003).

A role in signaling of the mobilization of seed storage reserves was suggested for a 
cloned Ser/Thr/Tyr kinase from peanut (Arachis hypogaea). This developmentally regulated DSK, different to MAPKs, is induced by abiotic stresses (Rudrabhatla \& Rajasekharan, 2002).

There are indications suggesting an involvement of protein tyrosine phosphorylation in the control of plant development (Mu et al., 1994; Barizza et al., 1999; Rudrabhatla \& Rajasekharan, 2002). Considerable protein tyrosine phosphorylation was detected in etiolated maize seedlings (Trojanek et al., 1996) at the intensive elongation phase, therefore presently we have focused on identification of a protein kinase responsible for this phosphorylation process.

\section{MATERIALS AND METHODS}

Biological material. Maize (Zea mays) seeds, after soaking for $24 \mathrm{~h}$ at room temperature in distilled water, were grown at $27^{\circ} \mathrm{C}$ for $72 \mathrm{~h}$ in the dark. The apical $1 \mathrm{~cm}$ of the etiolated seedlings was harvested into liquid $\mathrm{N}_{2}$, then stored at $-80^{\circ} \mathrm{C}$.

Chemicals. Mouse anti-phosphotyrosine antibody (PY-20) was from ICN Biochemicals, Immobilon P PVDF was from Millipore, TLC cellulose plastic sheets and $\mathrm{Na}_{2} \mathrm{CO}_{3}$ were from Merck, BCIP and NBT were from Promega, $\mathrm{P}-11$ phosphocellulose and 3MM paper were from Whatmann, $\left[\gamma^{32} \mathrm{P}\right] \mathrm{ATP}$ was from Amersham, Superose 12 column was from Pharmacia LKB, trichloroacetic acid was from Reachim, LMW, HMW, 2DE standards and Bio-Lyte 3/10 and 5/7 Ampholites were from BIO RAD. All other chemicals were from Sigma.

Buffers. Buffer A, $20 \mathrm{mM}$ Tris/ $\mathrm{HCl}, \mathrm{pH} 7.0$, $250 \mathrm{mM}$ sucrose, $25 \mu \mathrm{M} \mathrm{Na} \mathrm{VO}_{4}, 5 \mathrm{mM}$ EDTA, $1 \mathrm{mM}$ phenylmethylsulfonyl fluoride (PMSF); buffer B, $20 \mathrm{mM}$ Tris/HCl, $\mathrm{pH}$ 7.0, $25 \mu \mathrm{M} \mathrm{Na}_{3} \mathrm{VO}_{4}, 1 \mathrm{mM}$ EDTA, $0.1 \mathrm{mM}$ PMSF, $10 \mathrm{mM}$ 2-mercaptoethanol; buffer C, $50 \mathrm{mM}$ Tris/HCl, $\mathrm{pH}$ 7.5, $0.1 \mathrm{mM}$ EDTA, $10 \mu \mathrm{M}$ $\mathrm{Na}_{3} \mathrm{VO}_{4}, 10 \mathrm{mM}$ 2-mercaptoethanol, $10 \mathrm{mM}$
$\mathrm{MnCl}_{2}$; buffer D, $10 \mathrm{mM}$ Tris/HCl, $\mathrm{pH}$ 7.5, 1 mM EDTA, $30 \mu \mathrm{M} \mathrm{Na}{ }_{3} \mathrm{VO}_{4}, 10 \%$ (v/v) glycerol, 0.01\% (v/v) Triton X-100, 0.1 mM PMSF, $10 \mathrm{mM}$ 2-mercaptoethanol; buffer E, buffer B plus $10 \%$ (v/v) glycerol; buffer F, $50 \mathrm{mM}$ Tris/HCl, pH 8.0, 5 mM 2-mercaptoethanol; buffer TBST, $100 \mathrm{mM}$ Tris/HCl, $\mathrm{pH}$ 8.0, 50 $\mathrm{mM} \mathrm{NaCl}, 0.05 \%$ (v/v) Tween 20.

Purification of protein kinase(s). Purification procedures up to the first chromatography step were performed essentially as described previously (Trojanek et al., 1996) except that 10-fold more material was used. Fifty grams of frozen etiolated maize seedlings was ground in liquid $\mathrm{N}_{2}$ in a mortar, then transferred to a second mortar and mixed with $160 \mathrm{ml}$ of buffer A. The extract was centrifuged for $30 \mathrm{~min}$ at $100000 \times \boldsymbol{g}$ and the supernatant was filtered through glass wool before being applied to a phosphocellulose column (100 ml), equilibrated with buffer B. The column was washed with buffer $\mathrm{B}$, then eluted with a linear gradient of 0 to $0.8 \mathrm{M} \mathrm{NaCl}$ in buffer B (300 ml). Fractions of $3 \mathrm{ml}$ were collected and to each fraction glycerol was added to a final concentration of $10 \%$ $(\mathrm{v} / \mathrm{v})$. The enzymatically active fractions were pooled, dialyzed overnight against buffer $\mathrm{D}$, then applied to a poly L-lysine agarose column $(1.5 \mathrm{ml})$ previously equilibrated with buffer $\mathrm{E}$. The column was washed with buffer E, until the protein concentration was below 10 $\mu \mathrm{g} / \mathrm{ml}$, then the bound proteins were eluted with a linear gradient of 0 to $0.4 \mathrm{M} \mathrm{NaCl}$ in buffer E $(30 \mathrm{ml}) ; 1.5 \mathrm{ml}$ fractions were collected. All steps of the purification were performed at $4^{\circ} \mathrm{C}$. Protein concentration was estimated by Bradford's method (Bradford, 1976) using bovine serum albumin (BSA) as a standard.

Phosphorylation of synthetic polypeptide poly $\left(\mathrm{Glu}_{4}, \mathrm{Tyr}_{1}\right)$. Total reaction mixtures contained: the appropriate enzymatic fraction, $12.5 \mu \mathrm{M}\left[\gamma^{32}\right.$-P]ATP $(0.5 \mu \mathrm{Ci})$ and 2 $\mu \mathrm{M}$ poly $\left(\mathrm{Glu}_{4}, \mathrm{Tyr}_{1}\right)$ in buffer C. Phosphorylation of endogenous proteins without adding poly $\left(\mathrm{Glu}_{4}, \mathrm{Tyr}_{1}\right)$ was used as a reference. 
The ${ }^{32} \mathrm{P}$ incorporated in the reaction products was determined as described previously (Trojanek et al., 1996).

SDS/PAGE. Samples containing 0.2-2.0 $\mu \mathrm{g}$ of protein were subjected to the slab gel system of Laemmli (1970). Routinely, 10\% polyacrylamide gels were used. After electrophoresis, the gels were stained with silver, dried and autoradiographed.

Immunoblotting with anti-phosphotyrosine antibody. Proteins were precipitated by addition of trichloroacetic acid to a final concentration of $20 \%(\mathrm{v} / \mathrm{v})$ and after centrifugation washed with cold acetone and dried. The precipitates were dissolved in sample buffer, boiled, and proteins were separated on $10 \%$ polyacrylamide gel. Additionally, phosphotyrosine conjugated with BSA (as an antigen-positive control) was run on the gel. After SDS/PAGE, the proteins were transferred to Immobilon $\mathrm{P}$ in the buffer system containing $25 \mathrm{mM}$ Tris, $192 \mathrm{mM}$ glycine, $20 \%$ (v/v) methanol. Next, the membrane was blocked with $5 \%(\mathrm{v} / \mathrm{v})$ non-fat milk in TBST buffer for $1.5 \mathrm{~h}$ at room temperature followed by incubation with a 1:1000 diluted mouse anti-phosphotyrosine antibody in TBS for $1 \mathrm{~h}$ at room temperature with gentle rocking. Washing, incubation with secondary antibody and staining were performed as described previously (Trojanek et al., 1996).

Separation of phosphoamino acids by thin-layer chromatography. Enzymatic fraction $(100 \mu \mathrm{g})$ was phosphorylated in a mixture containing buffer $\mathrm{C}, 10 \mathrm{mM} \mathrm{MnCl}_{2}$ and $12.5 \mu \mathrm{M}\left[\gamma^{32} \mathrm{P}\right] \mathrm{ATP}(25 \mu \mathrm{Ci})$ alone, or with casein $(100 \mu \mathrm{g})$ or enolase $(100 \mu \mathrm{g})$ for 30 $\min$ at $30^{\circ} \mathrm{C}$. Then, trichloroacetic acid was added to a final $20 \%(\mathrm{v} / \mathrm{v})$ and the precipitated proteins were dissolved in sample buffer and separated by SDS/PAGE in 10\% gels. Samples containing proteins of appropriate molecular masses were cut out of the gels and extracted (Neufeld et al., 1989) in a buffer containing $50 \mathrm{mM} \mathrm{NaHCO}_{3}, 0.5 \%$ (v/v) SDS, and $32 \mathrm{mM}$ dithiothreitol (DTT). After $40 \mathrm{~h}$ incubation at room temperature, pro- teins were precipitated by $20 \%$ trichloroacetic acid and hydrolized in $6 \mathrm{M} \mathrm{HCl}$ for $2 \mathrm{~h}$ at $110^{\circ} \mathrm{C}$ in sealed glass tubes. After hydrolysis, the samples were lyophilized and the residues were dissolved in $100 \mu$ l water, relyophilized (two times), and finally dissolved in $15 \mu \mathrm{l}$ of water. Thin-layer chromatography was performed on cellulose plates according to a described procedure (Neufeld et al., 1989; Trojanek et al., 1996). Standards of Ser(P), $\operatorname{Thr}(\mathrm{P})$ and $\operatorname{Tyr}(\mathrm{P})$ were run in parallel and detected by reaction with $0.1 \%(\mathrm{w} / \mathrm{v})$ ninhydrin, whereas the ${ }^{32} \mathrm{P}$-labelled amino acids were detected by autoradiography.

In-gel kinase activity assay. Enzyme activity was measured in gel with immobilized substrates according to described procedure (Geahlen et al., 1986). Ten percent SDS/polyacrylamide gels contained $0.5 \mathrm{mg} / \mathrm{ml}$ copolymerized: $\operatorname{poly}\left(\mathrm{Glu}_{4}, \mathrm{Tyr}_{1}\right)$ or enolase. After electrophoresis, SDS was removed by washing the gels with washing buffer $(50 \mathrm{mM}$ Tris/HCl, $\mathrm{pH}$ 8.0, 20\% (v/v) 2-propanol) twice for 30 min each at room temperature; the gels were then equilibrated in buffer $\mathrm{F}$ (twice for $30 \mathrm{~min}$ ). Proteins were denaturated with $6 \mathrm{M}$ guanidine $\cdot \mathrm{HCl}$ in buffer $\mathrm{F}$ (twice for 30 $\mathrm{min}$ ), followed by overnight renaturation at $4^{\circ} \mathrm{C}$ in buffer $\mathrm{F}$ with $0.04 \%(\mathrm{v} / \mathrm{v})$ Tween 40 . Subsequently, the gels were incubated for $1 \mathrm{~h}$ at room temperature in $10 \mathrm{ml}$ of buffer $\mathrm{C}$ with $10 \mathrm{mM} \mathrm{MnCl} 2$ and $20 \mu \mathrm{M}$ ATP supplemented with $50 \mu \mathrm{Ci}\left[\gamma_{-}{ }^{32} \mathrm{P}\right] \mathrm{ATP}$. Reactions were terminated and unincorporated $\left[\gamma^{32}\right.$-P]ATP was removed by washing the gels with $5 \%(\mathrm{v} / \mathrm{v})$ trichloroacetic acid and $1 \%(\mathrm{v} / \mathrm{v})$ sodium phosphate. Finally the gels were stained with Coomassie Brilliant Blue R 250, dried, and exposed to Hyperfilm MP.

Two-dimensional electrophoresis (2DE) was carried out as described by O'Farrell (1975). Samples containing 10-20 $\mu \mathrm{g}$ protein were applied in buffer (9.5 M urea, $2 \%(\mathrm{v} / \mathrm{v})$ Triton X-100, 5\% (v/v) 2-mercaptoethanol, $1.6 \%(\mathrm{v} / \mathrm{v})$ Biolyte 5/7 ampholite, and 0.4\% (v/v) Biolyte 3/10 ampholite) on tube gels containing $4 \%(\mathrm{w} / \mathrm{v})$ acrylamide, $9.2 \mathrm{M}$ urea, 
$2 \%$ (v/v) Triton X-100, 1.6\% (v/v) Biolyte 5/7 ampholite, $0.4 \%$ (v/v) Biolyte 3/10 ampholite. The size of the tube gels was $45 \times 1 \mathrm{~mm}$. Isoelectric focusing was developed for $6 \mathrm{~h}$ at $435 \mathrm{~V}$ with $20 \mathrm{mM} \mathrm{NaOH}$ in the upper chamber and $10 \mathrm{mM} \mathrm{H}_{3} \mathrm{PO}_{4}$ in the lower chamber. Then, the gels were removed from the tubes and applied on second dimension 10\% slab gels (size $85 \times 55 \mathrm{~mm}, 1 \mathrm{~mm}$ thin). Electro- correlated with the peak of activity phosphorylating casein, which was about $50 \%$ higher than phosphorylation of tyrosine in poly $\left(\mathrm{Glu}_{4}, \mathrm{Tyr}_{1}\right)$ (Fig. 1A). This procedure resulted in 70-fold purification of the enzyme with more than $40 \%$ recovery (Table 1 ).

For further purification and estimation of the molecular mass of the protein kinase, the preparation after poly L-Lys chromatography

Table 1. Purification of protein kinase phosphorylating tyrosine from maize seedlings.

\begin{tabular}{llllcc}
\hline $\begin{array}{l}\text { Step of } \\
\text { purification }\end{array}$ & $\begin{array}{l}\text { Protein } \\
(\mathrm{mg})\end{array}$ & $\begin{array}{l}\text { Total activity } \\
\left(\mathrm{pmol} \cdot \mathrm{min}^{-1}\right)\end{array}$ & $\begin{array}{l}\text { Specific activity } \\
\left(\mathrm{pmol} \cdot \mathrm{min}^{-1} \cdot \mathrm{mg}^{-1}\right)\end{array}$ & $\begin{array}{l}\text { Fold of } \\
\text { purification }\end{array}$ & $\begin{array}{l}\text { Recovery } \\
\%\end{array}$ \\
\hline $\begin{array}{l}\text { Homogenate } \\
\text { P-cellulose }\end{array}$ & 352 & 686 & 2 & 1 & 20 \\
$\begin{array}{l}\text { Poly L-lysine } \\
\text { agarose }\end{array}$ & 17 & 651 & 38 & 70 & 95 \\
Superose 12 & 2 & 281 & 134 & 270 & 12 \\
\hline
\end{tabular}

Fifty grams of maize seedlings was used for the first three steps of purification. Three independent preparations after poly L-lysine/agarose chromatography were pooled concentrated and applied on Superose 12. For the determination of enzymatic activity poly $\left(\mathrm{Glu}_{4} \mathrm{Tyr}_{1}\right)$ was used as a substrate (see Materials and Methods).

phoresis was carried out for 45 min at $150 \mathrm{~V}$ and the gels were autoradiographed. The 2DE marker proteins were: conalbumin $76 \mathrm{kDa}, \mathrm{pI}$ 6.0-6.3, BSA $66 \mathrm{kDa}$, pI 5.4-5.6, actin 43 $\mathrm{kDa}, \mathrm{pI} 5.0-5.1$, carbonic anhydrase $31 \mathrm{kDa}$, pI 5.9-6.0.

\section{RESULTS}

\section{Purification and identification of the pro- tein kinase}

A protein kinase from maize seedlings phosphorylating Tyr was initially separated by chromatography on phosphocellulose as previously described (Trojanek et al., 1996). The enzymatically active fractions eluted by 0.2-0.3 $\mathrm{M} \mathrm{NaCl}$ gradient were further purified by chromatography on poly L-Lys/ agarose. The peak of activity phosphorylating Tyr in poly $\left(\mathrm{Glu}_{4}, \mathrm{Tyr}_{1}\right)$ eluted from immobilized poly L-lysine by $0.10-0.17 \mathrm{M} \mathrm{NaCl}$ was was subjected to gel filtration using a Superose 12 column attached to FPLC system. The activity toward phosphorylation of poly $\left(\mathrm{Glu}_{4}, \mathrm{Tyr}_{1}\right)$ or casein, eluted in a single peak with maximal activity corresponding to $55-57 \mathrm{kDa}$ (Fig. 1B). The same position of elution of both activities, as well as the symmetry of the peak eluted from the column indicate that only a single $\mathrm{PK}$ is present in the region of maximal activity (fr. 61-63). The small shoulder on the upper part of the elution (Fig. 1B, fr. 65-66) may suggest that another PK of about $45 \mathrm{kDa}$ is separated. By Superose gel filtration a further 4-fold purification of the $57 \mathrm{kDa}$ protein kinase was achieved. The specific activity of the $57 \mathrm{kDa}$ kinase was about $526 \mathrm{pmol} \cdot \mathrm{min}^{-1} \cdot \mathrm{mg}^{-1}(\mathrm{Ta}-$ ble 1). For identification of the protein kinase responsible for Tyr phosphorylation, the activity was monitored at different steps of purification by using the in-gel kinase assay with poly $\left(\mathrm{Glu}_{4}, \mathrm{Tyr}_{1}\right)$ as a substrate (Fig. 2A). Detection of activity at the different steps of pu- 
rification revealed a predominant $57 \mathrm{kDa}$ band. Immunoblot analysis with anti-phosphotyrosine antibody recognized a $57 \mathrm{kDa}$ protein in the fractions exhibiting maximal activity separated by poly L-lysine agarose
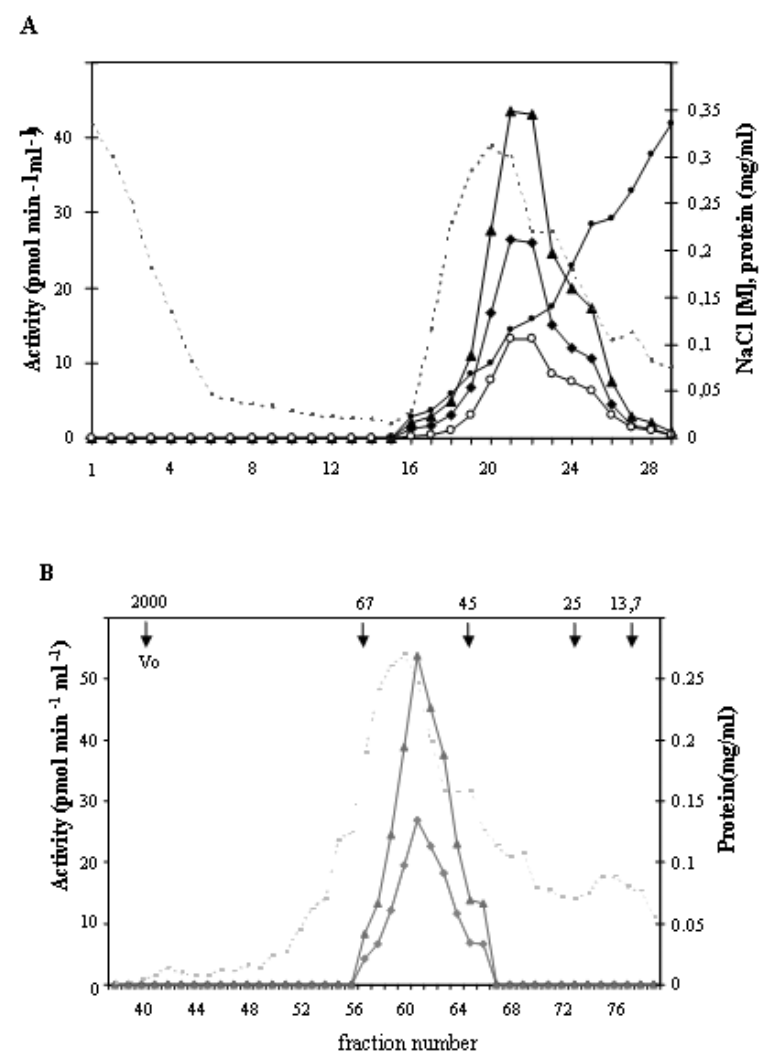

Figure 1. Elution profiles of protein kinase activity from poly L-Lys/agarose (A) and from Superose 12 (B).

The activity was assayed in solution as described in Materials and Methods using poly $\left(\mathrm{Glu}_{4} \mathrm{Tyr}_{1}\right)(\diamond)$ and casein ( $(\boldsymbol{\Delta})$ as substrates or without any substrate $(O)$; protein concentration is marked by the broken line whereas in $\mathrm{A} \mathrm{NaCl}$ concentration (O). Vertical arrows (left to right) (B) indicate the elution positions of the following molecular mass standards: blue dextran 2000 used for void volume $\left(\mathrm{V}_{\mathrm{o}}\right)$; bovine serum albumin (67 kDa), ovalbumin (45 kDa), chymotrypsinogen (25 $\mathrm{kDa})$, and ribonuclease $(13.7 \mathrm{kDa})$.

chromatography (Fig. 2B). These results confirm that the $57 \mathrm{kDa}$ protein(s) contains phosphotyrosine residues. Immunoblot analysis with anti-phosphotyrosine antibody confirmed the presence of the $57 \mathrm{kDa}$ protein in active fractions after the Superose 12 chromatography (Fig. 2C).
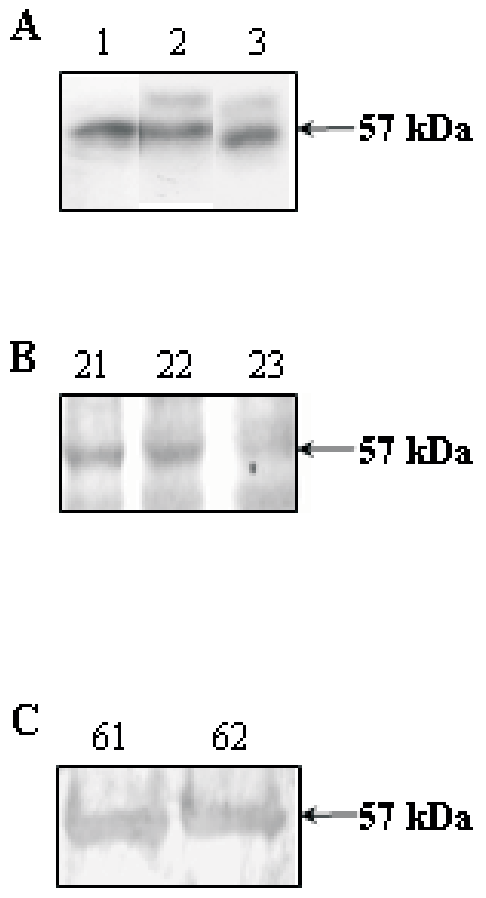

Figure 2. Identification of protein kinase phosphorylating tyrosine.

Protein kinases were analysed by in-gel kinase assay with immobilized poly $\left(\mathrm{Glu}_{4}, \mathrm{Tyr}_{1}\right)$ at different stages of purification (A) homogenate (lane 1), enzymes eluted from: P-cellulose column with 0.2-0.3 M NaCl (lane 2) and from poly L-Lys/agarose (lane 3) and Western blotting with anti-phosphotyrosine antibody of proteins from the enzymatically active fractions (frs. 21-23) after poly L-Lys/agarose (B) and Superose 12 chromatography (frs. 61 and 62) (C).

Two-dimensional electrophoresis (2 DE) was used to estimate the purity and isoelectric point of the isolated protein kinase. As can be seen from Fig. 3, the proteins of about $57 \mathrm{kDa}$ were phosphorylated. The more acidic protein (b) of pI about 5.2 was predominantly phosphorylated, whereas the second protein (a) probably occurred in three isoforms, differentially phosphorylated (pI about 5.8, 5.7, 5.6) (Fig. 3). 
Substrate specificity and modulation of enzymatic activity

Electophoretic separation of the proteins after gel filtration revealed the presence of other phosphorylable protein of $57 \mathrm{kDa}$ apart from protein kinase. This protein, which copurified with the studied protein kinase, was analysed by time-of-flight mass spectrometry (Q-TOF MS) and identified by the database computer program Mascot, (Perkins et $a l .$, 1999) as enolase (not shown). Therefore,

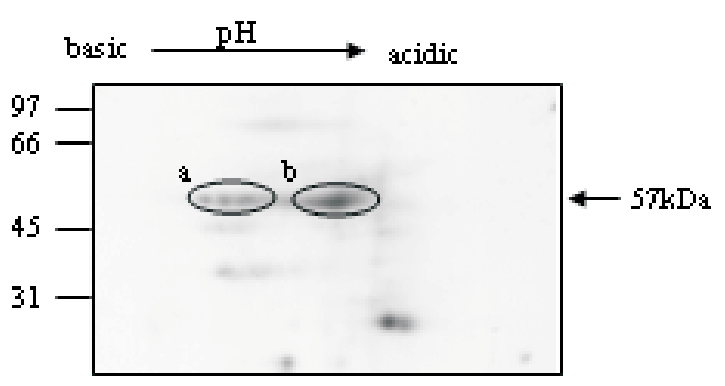

Figure 3. Separation of maize phosphoproteins by two-dimensional gel electrophoresis.

Autoradiogram of ${ }^{32} \mathrm{P}$-labelled proteins after gel filtration on Superose 12. Separated proteins are marked "a" and "b". Numbers indicate molecular mass standards in $\mathrm{kDa}$.

to test whether enolase can serve as a substrate of the $57 \mathrm{kDa}$ protein kinase, we used in-gel kinase assay with immobilized enolase (from rabbit muscle). High activity of the 57 $\mathrm{kDa}$ protein kinase toward phosphorylation of immobilized enolase was observed (Fig. 4B), while without immobilized enolase only traces of endogenous phosphorylation of the $57 \mathrm{kDa}$ protein could be detected (Fig. 4A). Also, other immobilized proteins, like casein, histone $\mathrm{H} 1$ or myelin baisc protein (MBP) were phosphorylated by $57 \mathrm{kDa}$ protein kinase (not shown).

Examination of the substrate specificity of the maize protein kinase was continued with in-solution assays using different substrates of PTKs: poly $\left(\mathrm{Glu}_{4}, \mathrm{Tyr}_{1}\right)$, $\operatorname{poly}\left(\mathrm{Glu}_{1}, \mathrm{Tyr}_{1}\right)$,
Src peptide (RRLIEDAEYAARG), enolase and commonly used substrates of protein kinases: casein, MBP, histones, phosvitin, casein kinase-1 substrate (RRKDLHDDEEDEAMSITA). The relative phosphorylation of the Src peptide and enolase was comparable to that of histones and most of caseins with the exception of kappa casein which showed approximately 3-fold higher phosphorylation. The specific substrates of casein kinases, namely phosvitin and casein kinase- 1 substrate, were not phosphorylated (Fig. 5).

Further characterization of the maize protein kinase involved an elucidation of the effect of various modulators of mammalian PTKs on the plant enzyme. Specific inhibitors of mammalian enzymes: genistein, an erbstatin analogue, herbimycine $\mathrm{A}$ and tryphostine AG 126 and PP1 even at high concentrations $(370,100,44,232$ and $178 \mu \mathrm{M}$, respectively) did not affect the activity of the

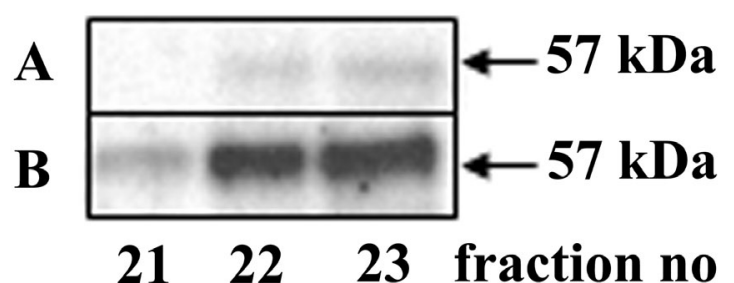

Figure 4. Phosphorylation of enolase by $57 \mathrm{kDa}$ maize protein kinase.

Activity of three fractions after poly L-Lys/agarose chromatogtraphy was tested by in-gel kinase assay without (A) and with (B) immobilized enolase.

maize protein kinase (not shown). Only lavendustine showed some effect on the phosphorylation of poly $\left(\mathrm{Glu}_{4}, \mathrm{Tyr}_{1}\right) \quad\left(\mathrm{IC}_{50} 68.8\right.$ $\mu \mathrm{M})$. Poly L-lysine and heparin, activators of mammalian PTKs, inhibited the activity of the maize enzyme, but staurosporine, which is a general inhibitor of protein kinases, exhibited the strongest inhibitory effect. Inhibition of poly $\left(\mathrm{Glu}_{4}, \mathrm{Tyr}_{1}\right)$ phosphorylation by staurosporine was more pronounced than casein $\left(\mathrm{IC}_{50} 0.074\right.$ and $0.620 \mu \mathrm{M}$, respectively) 


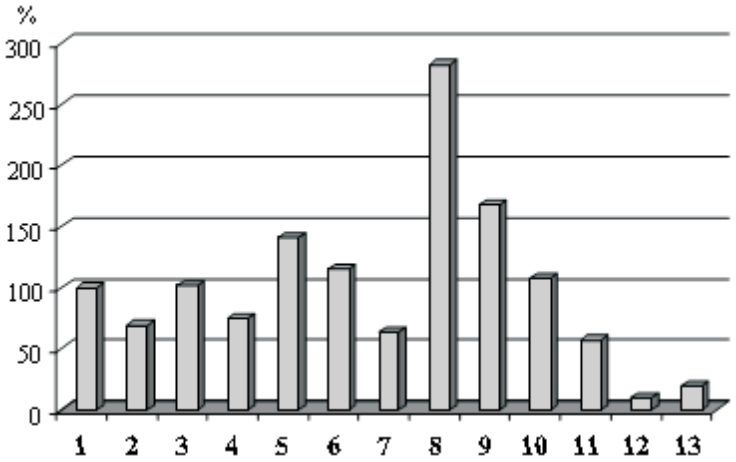

Figure 5. Substrate specificity of maize protein kinases.

The following peptides and proteins were tested: poly $\left(\mathrm{Glu}_{4} \mathrm{Tyr}_{1}\right.$ ) (1), poly(Glu $\mathrm{Tyr}_{1}$ ) (2), Src peptide (3), enolase (4), whole casein (5), $\alpha$-casein (6), $\beta$-casein (7), $\kappa$-casein (8), MBP (9), histone H1 (10), histone H2b (11), phosvitin (12), and casein kinase 1 substrate (13). The activity with the peptides and proteins was tested at $0.1 \mathrm{mg} / \mathrm{ml}$ except of the Src peptide $-7.6 \mathrm{mg} / \mathrm{ml}$ (1.25 mM). Phosphorylation of Tyr in poly $\left(\mathrm{Glu}_{4} \mathrm{Tyr}_{1}\right)$ was taken as 100 .

(Table 2). To confirm the inhibition results observed in solution, the gel-kinase assays were performed. Staurosporine at $0.5 \mu \mathrm{M}$ inhibited fully the activity of $57 \mathrm{kDa}$ protein kinase (Fig. 6, lane 1), whereas at lower concentrations $(0.1$ and $0.05 \mu \mathrm{M})$ only traces of the activity were visible (Fig 6 , lane 2 , 3). Genistein and lavendustin had no major effect on the activity of the plant enzyme (Fig. 6, lanes 4-7).

\section{Identification of phosphorylated amino ac- ids}

In order to establish which amino acids were phosphorylated by the maize protein kinase, casein, enolase and maize protein fraction of $57 \mathrm{kDa}$ were subjected, after phosphorylation, to acid hydrolysis followed by TLC separation of ${ }^{32}$ P-labelled amino acids and autoradiography (Fig. 7). The positions of phosphoamino acids were estimated based on the position of ninhydrin-stained spots of P-Tyr, P-Thr and P-Ser standards spotted in parallel

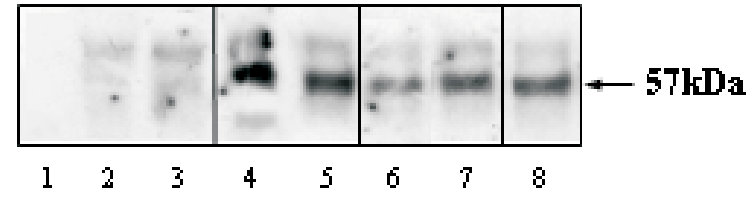

Figure 6. Effect of selected protein kinases inhibitors on the activity of maize protein kinase.

The enzyme activity was assayed by in-gel kinase assay with immobilized poly $\left(\mathrm{Glu}_{4}, \mathrm{Tyr}_{1}\right)$ in the presence of staurosporine: $0.5 \mu \mathrm{M}$ (lane 1), $0.1 \mu \mathrm{M}$ (lane 2), 0.05 $\mu \mathrm{M}$ (lane 3); genistein: $185 \mu \mathrm{M}$ (lane 4), $92.5 \mu \mathrm{M}$ (lane 5); lavendustin: $131 \mu \mathrm{M}$ (lane 6), $65.5 \mu \mathrm{M}$ (lane 7); and the enzyme alone (lane 8).

with the hydrolysates. In the case of the endogenously phosphorylated $57 \mathrm{kDa}$ proteins, two radioactive spots were present: P-Tyr and P-Ser (Fig 7, lane 3). Tyr and Ser were also intensively phosphorylated in casein and enolase (Fig. 7, lanes 1 and 2) but only traces of P-Thr were visible.

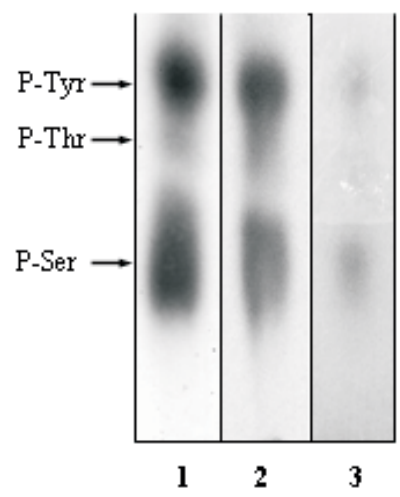

Figure 7. Thin-layer chromatography of $\left[{ }^{32} \mathrm{P}\right]$ phosphoamino acids in acid hydrolysate of ${ }^{32} \mathrm{P}$-labelled proteins (autoradiogram).

Proteins phosphorylated by maize protein kinase: whole casein (lane 1), enolase (lane 2), and endogenous phosphorylation of $57 \mathrm{kDa}$ maize proteins (lane 3).

\section{DISCUSSION}

A protein kinase phosphorylating Tyr residues was partially purified from etiolated maize seedlings by chromatography on P-cellulose and poly L-Lys/agarose. The molecular 
mass of the kinase was estimated by in-gel kinase assay as $57 \mathrm{kDa}$. Moreover, gel filtration chromatography in nondenaturating conditions showed molecular masses in the range of $55-57 \mathrm{kDa}$, indicating that the $57 \mathrm{kDa}$ kinase is enzymatically active as a monomer.

Poly L-lysine, a known activator of PTKs, had an inhibitory effect on the plant enzyme. The inhibition was dependent on the substrate, which suggests that poly L-lysine could modulate the interaction of the protein kinase with particular substrates (Abdel-Ghany et al., 1990). Poly L-lysine might interact with the substrates and induce conformational changes that make them either more or less available for phosphorylation. Our results indicate that in addition to the postulated role of this polycation as a substrate modulator,
Staurosporine, a non-specific inhibitor of protein kinases, efficiently inhibited the activity of the $57 \mathrm{kDa}$ protein kinase from maize seedlings. Staurosporine binds with an extraordinarily high affinity (1-20 nM) to most Ser/Thr protein kinases (Prade et al., 1997), and with a lower affinity (10-1000 nM) to PTKs (Secrist et al., 1990). Staurosporine bound to the adenosine pocket of protein kinase A catalytic subunit causes a considerably induced fit rearrangement of the enzyme, yielding a unique open conformation. This inhibitor can induce a variety of conformational changes of neighboring enzyme residues (Prade et al., 1997). However, a few protein kinases are relatively insensitive to staurosporine. Namely, Ser/Thr kinases: CK1 and CK2, MAPK, CaM-kinase III, and ty-

Table 2. Influence of effectors of mammalian tyrosine kinases on the activity of maize protein kinase phosphorylating tyrosine

\begin{tabular}{llll}
\hline \multirow{2}{*}{ Effector } & \multirow{2}{*}{$\begin{array}{l}\text { Concentration used } \\
{[\mu \mathrm{M}]}\end{array}$} & \multicolumn{2}{c}{$\mathrm{IC}_{50}[\mu \mathrm{M}]$} \\
\cline { 3 - 4 } & $0.02-20$ & 0.074 & casein \\
\hline Staurosporine & $16.4-131$ & 68.8 & 0.620 \\
Lavendustin A & $0-5.5$ & 0.982 & - \\
Poly L-lysine & $0-24.9$ & 2.76 & 0.118 \\
Heparin & & & - \\
\hline
\end{tabular}

-, lack of inhibition.

poly L-Lys efficiently binds the maize protein kinase. This affinity was exploited for efficient purification of the enzyme using poly L-Lys immobilized on agarose. The polyanion heparin also inhibited the maize enzyme in a substrate dependent manner. A strong inhibition of the enzymatic activity was observed when poly $\left(\mathrm{Glu}_{4}, \mathrm{Tyr}_{1}\right)$ was used as a substrate, whereas casein phosphorylation was not effected by heparin (Table 2). In contrast, phosphorylation of casein by mammalian protein tyrosine kinases was inhibited by heparin (Wong \& Goldberger, 1984; Borowski et al., 1993). rosine kinases: CSK (C-Src kinase) and IGF-IR which are inhibited by micromolar concentration of staurosporine (Meggio et al., 1995).

Genistein is often used as a diagnostic inhibitor of PTKs (Akiyama et al., 1987) and has been shown to inhibit protein Tyr phosphorylation in a plant signal system (Håkansson \& Allen, 1995; Islas-Flores et al., 1998; Rodriguez-Zapata \& Hernández-Sotomayor, 1998). In contrast, the maize $57 \mathrm{kDa}$ protein kinase, although it phosphorylates Tyr residues, was not inhibited by genistein. 
Data on $A$. thaliana genome sequencing does not show sequences homologous with typical PTKs (European Union Arabidopsis Genome Sequencing Consortium, and The Cold Spring Harbor, Washington University in St. Louis, and PE Biosystems Arabidopsis Sequencing Consortium, 1999). There are, however, molecular indications that DSKs are responsible for Tyr phosphorylation of plant proteins (Hirayama \& Oka, 1992; Ali et al., 1994; $\mathrm{Mu}$ et al., 1994). Presently, we provide biochemical data showing that the properties of the $57 \mathrm{kDa}$ maize protein kinase are similar to those of dual specificity protein kinases. These include broad substrate specificity and the ability to phosphorylate Tyr as well as Ser in exogenous and endogenous proteins. The maize protein kinase was able to phosphorylate Tyr residues in exogenous substrates of PTK such as poly $\left(\mathrm{Glu}_{4}, \mathrm{Tyr}_{1}\right)$ and the Src peptide, but also Ser and Tyr residues in casein and enolase. Besides, the maize protein kinase was able to phosphorylate Tyr and Ser residues in endogenous proteins. The broad substrate specificity distinguishes the $57 \mathrm{kDa}$ protein kinase from the known dual specificity MAP kinase kinases (MAPKKs). In contrast to the maize kinase, MAPKK from the cell line A 431 stimulated by epidermal growth factor, phosphorylated MBP and histones with low efficiency and was not able to phosphorylate poly $\left(\mathrm{Glu}_{4}, \mathrm{Tyr}_{1}\right)$ and Src (Seger et al., 1992). Also casein kinases 1 and 2 (CK1 and CK2) seem to be dual specificity kinases because in vitro they are able to phosphorylate Tyr residues (Hoekstra et al., 1994; Wilson et al., 1997; Marin et al., 1999). It was documented that yeast isotypes of CK1 were autophoshorylated on tyrosine and were able to phosphorylate poly $\left(\mathrm{Glu}_{4}, \mathrm{Tyr}_{1}\right.$ ), (Hoekstra et al., 1994). However, substrates of casein kinases, namely phosvitin and the peptide RRKDLHDDEEDEAMSITA (Marin et al., 1994), were not phosphorylated by the maize kinase. Lack of phosphorylation of this peptide which seems to be relatively specific for CK1 (Pulgar et al., 1996), the opposite effect of poly L-lysine, which is a stimulator of CK2 activity, and a significantly different affinity for heparin and staurosporine, suggest that the $57 \mathrm{kDa}$ maize protein kinases does not belong to the any of the CK classes of enzymes. Thus, our results provide biochemical data indicating that maize protein kinase phosphorylating Tyr is a novel plant dual specificity protein kinase.

Enolase is a candidate as an endogenous substrate of the maize kinase. Such suggestion is supported by the facts that enolase copurified with the maize kinase and that this kinase phosphorylates Tyr and Ser in rabbit muscle enolase.

The partly purified enzymatic preparation of $57 \mathrm{kDa}$ protein kinase after endogenous phosphorylation was resolved by two-dimensional electrophoresis into several phosphorylated species. Different isoelectric points of three proteins (marked as "a" on Fig. 3) may suggest that a single protein undergoes differential phosphorylation. There are indications that maize enolase of apparent molecular masses of 55 and $56 \mathrm{kDa}$ can be resolved into three isoforms upon two-dimensional electrophoresis (Lal et al., 1994). The phosphorylation at tyrosine residues of two enolase isoenzyms from chicken fibroblast has revealed different forms of pI 5.2-6.7 (Eigenbrodt et al., 1983). Because the amino-acid sequence of enolase from different species is highly conserved e.g. maize enolase shows $82 \%$ identity with human enolase, it is possible that in maize enolase, like in vertebrates, tyrosine undergoes phosphorylation. Moreover, the $A$. thaliana protein kinase APK1, which is a dual specificity kinase, is able to phosphorylate enolase (Hirayama \& Oka, 1992).

Further investigation will focus on molecular characterization of the maize PK phosphorylating Tyr and elucidation of the role of endogenous substrates of the maize DSKs. 
We thank Professors Jan Miernyk, Piotr Lassota and Michał Dadlez for critical advice, Jacek Sikora and Jacek Olędzki for mass spectrometry analysis and Katarzyna Róg for help in preparation of the manuscript.

\section{R E F E R E N C E S}

Abdel-Ghany M, El-Gendy K, Zhang S, Racker E. (1990) Control of Src kinase activity by activators inhibitors and substrate chaperones. Proc Natl Acad Sci USA.; 87: 7061-5.

Akiyama T, Ishida J, Nakagawa S, Ogawara H, Watanabe Sh-i, Itoh N, Shibuya M, Fukami Y. (1987) Genistein a specific inhibitor of tyrosine-specific protein kinases. J Biol Chem.; 262: $5592-5$.

Ali N, Halfter U, Chua N-H. (1994) Cloning and biochemical characterization of a plant protein kinase that phosphorylates serine threonine and tyrosine. J Biol Chem.; 269: 31626-9.

Asai T, Guillaume T, Plotnikova J, Willman MR, Chiu W-L, Gomez-Gomez L, Boller T, Ausubel FM, Sheen J. (2002) MAP kinase signaling cascade in Arabidopsis innate immunity. Nature.; 415: 977-83.

Barizza E, Schiavo FL, Terzi M, Filippini F. (1999) Evidence suggesting protein tyrosine phosphorylation in plants depends on the developmental conditions. FEBS Lett.; 447: 191-4.

Borowski P, Medem S, Laufs R. (1993) Biochemical properties of a novel $28 \mathrm{kD}$ protein tyrosine kinase partially purified from the particulate fraction of rat spleen. Biochem Biophys Res Commun.; 197: 646-53.

Bradford MM. (1976) A rapid and sensitive method for the quantitation of microgram quantities of protein utilizing the principle of protein-dye binding. Anal Biochem.; 72: 248-54.

Chang C. (2003) Ethylene signaling: the MAPK module has finally landed. Trends Plant Sci.; 8: $365-8$.
Cooper JA, Sefton BM, Hunter T. (1983) Detection and quantification of phosphotyrosine in proteins. Methods Enzymol.; 99: 387-402.

Dhanasekaran N, Reddy EP. (1998) Signaling by dual specificity kinases. Oncogene.; 17: 1447-55.

Eigenbrodt E, Fister P, Rübsamen H, Friis RR. (1983) Influence of transformation by Rous sarcoma virus on the amount phosphorylation and enzyme kinetic properties of enolase. EMBO J.; 2: 1565-70.

Elliot DC, Geytenbeek M. (1985) Identification of products of proteins phosphorylation in T37-transformed cells and comparison with normal cells. Biochim Biophys Acta.; 845: $317-23$.

European Union Arabidopsis Genome Sequencing Consortium and The Cold Spring Harbor Washington University in St. Louis and PE Biosystems Arabidopsis Sequencing Consortium (1999) Nature.; 402: 769-77.

Geahlen RL, Anostario M, Low PS, Harrison ML. (1986) Detection of protein kinase activity in sodium dodecyl sulfate-polyacrylamide gels. Anal Biochem.; 153: 151-8.

Guillén G, Valdés-Lopez V, Noguez R, Olivares J, Rodriquez-Zapata LC, Pérez H, Vidali L, Villanueva MA, Sanchez F. (1999) Profilin in Phaseolus vulgaris is encoded by two genes (only one expressed in root nodules) but multiple isoforms are generated in vivo by phosphorylation on tyrosine residues. Plant J.; 19: 497-508.

Guo H, Ecker JR. (2004) The ethylene signaling pathway: new insights. Curr Opin Plant Biol.; 7: 40-9.

Håkansson G, Allen JF. (1995) Histidine and tyrosine phosphorylation in pea mitochondria: evidence for protein phosphorylation in respiratory redox signalling. FEBS Lett.; 372: $238-42$.

Hirayama T, Oka A. (1992) Novel protein kinase of Arabidopsis thaliana (APK1) that phosphorylates tyrosine serine and threonine. Plant Mol Biol.; 20: 653-62.

Hoekstra MF, Dhillon N, Carmel G, DeMaggio AJ, Lindberg RA, Hunter T, Kuret J. (1994) 
Budding and fission yeast casein kinase I isoforms have dual-specificity protein kinase activity. Mol Biol Cell.; 5: 877-86.

Hunter T. (1998) The Croonian Lecture 1997. The phosphorylation of proteins on tyrosine: its role in cell growth and disease. Philos Trans $R$ Soc Lond Biol Sci.; 353: 583-605.

Islas-Flores I, Oropeza C, Hernández-Sotomayor T. (1998) Protein phosphorylation during coconut zygotic embryo development. Plant Physiol.; 118: 257-63.

Kiegeri S, Cardinale F, Siligan Ch, Gross A, Baudouin E, Liwosz A, Eklöf S, Till S, Bögre L, Hirt H, Meskiene I. (2000) SIMKK a mitogen-activated protein kinase (MAPK) kinase is a specific activator of the salt stress-induced MAPK SIMK. Plant Cell.; 12: 2247-58.

Laemmli UK. (1970) Cleavage of structural proteins during the assembly of the head of bacteriophage T4. Nature.; 227: 680-5.

Lal SK, Kelley PM, Elthon TE. (1994) Purification and differential expression of enolase from maize. Physiol Plant.; 91: 587-92.

Lindberg RA, Quinn AM, Hunter T. (1992) Dual-specificity protein kinases: will any hydroxyl do? Trends Biochem Sci.; 17: 114-9.

Luan S. (2002) Tyrosine phosphorylation in plant cell signaling. Proc Natl Acad Sci USA.; 99: 11567-9.

Marin O, Meggio F, Pinna LA. (1994) Design and synthesis of two new peptide substrates for the specific and sensitive monitoring of casein kinases-1 and -2. Biochem Biophys Res Commun.; 198: 898-905.

Marin O, Meggio F, Sarno S, Cesaro L, Pagano MA, Pinna LA. (1999) Tyrosine versus serine/threonine phosphorylation by protein kinase casein kinase-2 J Biol Chem.; 274: 29260-5.

Meggio F, Donella Deana A, Ruzzene M, Brunati AM, Cesaro L, Guerra B, Meyer T, Mett H, Fabbro D, Furet P, Dobrowolska G, Pinna LA. (1995) Different susceptibility of protein kinases to staurosporine inhibition. Kinetic studies and molecular bases for the resistance of protein kinase CK2. Eur $J$ Biochem.; 234: 317-22.

Morris PC, Guerrier D, Leung J, Giraudat J. (1997) Cloning and characterization of MEK1 an Arabidopsis gene encoding a homologue of MAP kinase kinase. Plant $\mathrm{Mol}$ Biol.; 35: 1057-64.

Neufeld E, Goren J, Boland D. (1989) Thin-layer chromatography can resolve phosphotyrosine phosphoserine, and phosphothreonine in a protein hydrolyzate. Anal Biochem.; 177: 138-43.

Ouaked F, Rozhon W, Lecourieux D, Hirt H. (2003) A MAPK pathway mediates ethylene signaling in plants. EMBO J.; 22: 1282-8.

O’Farrell PH. (1975) High resolution two-dimensional electrophoresis of proteins. $J$ Biol Chem.; 250: 4007-21.

Perkins DN, Pappin DJ, Creasy DM, Cottrell JS. (1999) Probability-based protein identification by searching sequence database using mass spectrometry data. Electrophoresis.; 20: 3551-67.

Prade L, Engh RA, Girod A, Kinzel V, Huber R, Bossemeyer D. (1997) Staurosporine-induced conformational changes of cAMP-dependent protein kinase catalytic subunit explain inhibitory potential. Structure.; 5: 1627-37.

Pulgar V, Tapia C, Vignolo P, Santos J, Sunkel CE, Allende CC, Allende JE. (1996) The recombinant $\alpha$ isoform of protein kinase CK1 from Xenopus laevis can phosphorylate tyrosine in synthetic substrates. Eur J Biochem.; 242: 519-28.

Rodriguez-Zapata LC, Hernández-Sotomayor T. (1998) Evidence of protein-tyrosine kinase activity in Catharanthus roseus roots transformed by Agrobacterium rhizogenes. Planta.; 204: $70-7$.

Rudrabhalta P, Rajasekharan R. (2002) Developmentally regulated dual-specificity kinase from peanut that is induced by abiotic stresses. Plant Physiology.; 130: 380-90.

Savaldi-Goldstein S, Aviv D, Davydov O, Fluhr R. (2003) Alternative splicing modulation by LAMMER kinase impinges on developmental 
and transcriptome expression. Plant Cell.; 15: $926-38$.

Secrist JP, Sehgal I, Powis G, Abraham RT. (1990) Preferential inhibition of the platelet derived growth factor receptor tyrosine kinase by staurosporine. J Biol Chem.; 265: 20394-400.

Seger R, Ahn NG, Posade J, Munar ES, Jensen AM, Cooper JA, Cobb MH, Krebs EG. (1992) Purification and characterization of mitogen-activated protein kinase activator(s) from epidermal growth factor - stimulated A431 cells. J Biol Chem.; 267: 14373-81.

Sessa G, Raz V, Savaldi S, Fluhr R. (1996) PK12 a plant dual-specificity protein kinase of the LAMMER family is regulated by the hormone ethylene. Plant Cell.; 8: 2223- 34.

Skirpan AL, McCubbin AG, Ishimizu T, Wang X, Dowd PE, Ma H, Kao T-h. (2001) Isolation and characterization of kinase interacting protein 1 a pollen protein that interacts with the kinase domain of PRK1 a receptor-like kinase of Petunia. Plant Physiol.; 126: 1480-92.

Torruella M, Casano LM, Vallejos RH. (1986) Evidence of the activity of tyrosine kinase(s) and of the presence of phosphotyrosine proteins in pea plantlets. $J$ Biol Chem.; 261: 6651-3.

Trojanek J, Ek P, Scoble J, Muszyńska G, Engström L. (1996) Phosphorylation of plant proteins and the identification of protein-tyrosine kinase activity in maize seedlings. Eur J Biochem.; 235: 338-44.

Uchida T, Matozaki T, Noguchi T, Yamato T, Horita K, Suzuki T, Fujioka Y, Sakamoto C, Kasuga M. (1994) Insulin stimulates the phosphorylation of Tyr ${ }^{538}$ and the catalytic activity of PTP1C a protein tyrosine phosphatase with Src homology-2 domains. $J$ Biol Chem.; 269: 12220-8.

Wilson LK, Dhillon N, Thorner J, Martin GS. (1997) Casein kinase II catalyzes tyrosine phosphorylation of the yeast nucleolar immunophilin Fpr.3. J Biol Chem.; 272: 12961-7.

Wong TW, Goldberg AR. (1984) Purification and characterization of the major species of tyrosine protein kinase in rat liver. $J$ Biol Chem.; 259: 8505-12. 